\title{
PENGEMBANGAN BUKU SAKU BERBASIS LITERASI SAINS UNTUK MENINGKATKAN KEMAMPUAN BERFIKIR KRITIS SISWA DALAM PEMBELAJARAN IPA DI MADRASAH
}

\section{Development of Science Literacy-Based Pocket Books to Improve Students' Critical Thinking Skills in Science Learning in Madrasahs}

\author{
Rian Vebrianto ${ }^{1 *}$ \\ Dina Istiqomah ${ }^{2}$ \\ *IPendidikan Guru Madrasah \\ Ibtidaiyah, Universitas Islam \\ Negri Sultan Syarif Kasim Riau \\ *2 Pasca Sarjana PGMI Uin \\ Sultan Syarif Kasim Riau \\ *email: \\ Vebrianto@uin_suska.ac.id
}

\section{Kata Kunci:}

Buku saku,

Berbasis Literasi Sains,

Pembelajaran IPA

\section{Keywords:}

pocket book, science literacy

based, science learning

Accepted

Juli 2021

\section{Published}

Agustus 2021

\begin{abstract}
Abstrak
Dalam proses pembelajaran tidak bisa dipingkiri lagi bahwa pentinnya menggunakan media yang tepat yang dapat mendukung proses pembelajaran lebih cepat dan tepat lagi sampai ke peserta didik, pada masa dewasa ini proses pembelajaran dituntuk lebih kreatif, inovatif dengan menggunakan media yang pasti dan jelas. Untuk itu muncullah buku saku berbasis literasi sains yang akan menunjang proses pembelajaran peserta didik dalam pembelajaran IPA. Objek kajian ini lebih memudahkan siswa dalam proses pembelajaran IPA dengan adanya media buku saku berbasis literasi sains.
\end{abstract}

\begin{abstract}
In the learning process it cannot be denied that it is important to use the right media that can support the learning process more quickly and accurately to the students, at this time the learning process is intended to be more creative, innovative using clear and definite media. For this reason, a scientific literacy-based pocket book emerged which would support the learning process of students in science learning. The object of this study makes it easier for students in the science learning process by means of a pocket book media based on scientific literacy.
\end{abstract} (C) 202I The Authors. Published by Institute for Research and Community Services Universitas Muhammadiyah Palangkaraya. This is Open Access article under the CC-BY-SA License (http://creativecommons.org/licenses/bysa/4.0/).

\section{PENDAHULUAN}

Semakin pesatnya perkembangan ilmu pengetahuan dan teknologi di abad 21 memberikan tantangan tersendiri kepada dunia pendidikan. Siswa diharapakan dimana siswa tersebut tidak hanya memiliki atau menguasai aspek kognitif saja, demikian juga harus mengimbangi dengan kemampuan berfikir kritis pada siswa yang efektif digunakan dalam menghadapi masa depan. Keterampilan berpikir yang dibutuhkan di abad 21 adalah berpikir kritis (Kharbach, 20I2). Diantara tujuan pendidikan di Indonesia salah satu tujuan nya yaitu agar peserta didik/siswa mampu berfikir secara kritis terhadap apa yang ditemuinya baik di dalam pembelajaran maupun didalam kehidupan sehari-hari (Hassani dan Rahmatkah, 20l4). Moon (2008) juga menegaskan bahwa keterampilan berpikir kritis ini sangat diperlukan demi tercapainya tujuan pendidikan. Salah satu kemampuan yang harus dikembangkan sejak dini diantaranya yaitu kemampuan berfikir kritis (Friedrichsen, 2001:562). Namun, pada saat ini, hanya sedikit sekolah yang menerapkan pembelajaran yang mengarahkan pada pengembangan keterampilan berpikir kritis (Santrok, 20ll). Diantara tujuan sekolah dan pendidikan salah satu diantaranya yaitu mengasah kemampuan berfikir kritis pada siswa, mengambil keputusan secara rasional mengenai apa yang diyakini dan diperbuat (Nur dan Wikandari, 2008). Widowati (2009) juga mengemukakan pendidikan masa kini diantaranya pendidikan formal 
cendrung hanya mengaju dan terjebak pada lower order of thingking dimana pada pendapat ini hanya menekankan pada mengingat dan memahami. Dengan demikian sangat penting atau sangat dibutuhkan pembelajaran pada siswa yang lebih mengembangkan kemampuan berfikir kritis atau berfiki tingkat tinggi untuk mengahadapi lingkungan sekitar demi kenyamanannya dimasa depan. Salah satu pendapat yang mngatakan bahwa berfikir kritis merupakan cara berfikir yang reflektif yang berhubungan dengan nalar manusia itu sendiri yang masuk akal dan apa yang dilakukan dan yang diyakini menjadi titik kefokusan (Ennis 2000). Dan pendapat lain yaitu yang mengatakan bahwa berfikir kritis merupakan berfikir kritis itu sama hal nya dengan keadaan seorang yang membhat suatu konsep kemudian orang tersebut mengaplikasikannya lalu menganalisis kemudian mensintetis dan yang terahir mengevaluasi berbagai macam informasi lebih lanjut, Walker (2006) mengemukakan bahwa berpikir kritis merupakan suatu proses intelektual dalam membuat suatu konsep, mengaplikasikan, menganalasis, mensintesis, dan mengevaluasi berbagai macam informasl yang telah didapatkan oleh observasi baik itu berupa pengalaman ataupun hal yang lainnya kemudian diajadikan acuan untuk mengambil keputusan. Mata pelajaran Ilmu Pengetahuan Alam (IPA) di madrasah mengajarkan tentang konsep-konsep dasar dan memperkenalkan kepada siswa tentang alam sekitar. Susilo, dkk (2012:13) mengatakan bahwa IPA berupaya agar siswa dapat mempelajari keterampilan proses dalam pembelajaran ipa secara ilmiah dalam kehidupannya dimasyarakat dalam kehidupan seharihari, sehingga dapat menumbuhkan keterampilan berpikir siswa terutama kemampuan berpikir kritis. Sejalan dengan hal tersebut Kurniawati dkk (20l4) menyatakan bahwa dalam proses pembelajaran siswa diharapkan dapat mengembangkan kemampuan berpikir kritis yang dapat dipergunakan untuk menganalisis pikirannya dalam menentukan pilihan dan menarik kesimpulan.

\section{Latar Belakang Masalah}

Lemahnya proses pembelajaran saat ini menjadi permasaahan serius di Negara kita indonesia (Sanjaya, 20II:II). Kecenderungan dalam kegiantan pembelajaran IPA belum sepenuhnya mampu mengoptimalkan kemampuan berpikir siswa. Disebabkan masih terbatasnya alat peraga ataupun alat maupun media didalam pembelajaran menjadi alasan yang sangat kuat yang dijadikan oleh guru/pengajar ketika ditanya atau di persoalkan tentang partisipasi siswa dalam proses pembelajaran. Permasalahan lain dalam proses pembelajaran IPA adalah memperkecil kesenjangan kemampuan akademik antara siswa yang memiliki kemampuan akademik berbeda. Siswa yang berkemampuan akademik bawah dapat mendekati siswa berkemampuan akademik atas jika memperoleh scaffolding dari guru dan teman sebaya. Dalam pembelajaran IPA di madrasah hal yang sangat perlu atau penting untuk dikembangkan salah satunya adalah kemampuan berfikir kritis siswa, karena hal tersebut akan menimbulkan efek yang tentunya sangat ketika kegiatan pembelajaran siswa kedepannya didalam kegiatan pembelajaran IPA bait itu pembelajaran IPA di tingkat sekolah menengah perta (SMP) atau sekolah menengah atas (SMA) dan seterusnya, dengan terlatihnya kemampuan berfikir kritis pada siswa di madrasah akan menumbuhkan kemandirian terhadap siswa sejak dini hal tersebut akan menjadikan siswa lebih mampu memecahkan permasalahan yan g dihadapinya dengan lingkungan sekitar dalam kehidupan sehari-hari. Terlepas dari hal tersebut siswa pada tignkat madrasah sudah mempunyai bekal yaitu dasar pengetahuan walaupun sifatnya masih terbatas dengan hal ini sangat memungkinkan untuk siswa agar kemampuan berfikir kritisnya lebih diasah dan terlatih (Lambertus, 2009). Pendapat lain yang mendukung pendapat Lambertus yaitu pendapat Piaget (dalam japa,2008) ia mengatakan bahwa.

tingkat kemampuan berfikir kritis siswa sudah ada sejak ia di bangku madrasah tepatnya pada jenjang kelas lima pendidikan formal siswa sudah mempunya potensi kemampuan untuk berfikir kritis namun untuk menumbuhkan kemampuan tersebut diperlukan latihan secara terus menerus sejak dini dengan cara latihan maka hal tersebut akan menjadi suatu kebiasaan bagi siswa. Berfikir secara jelas, pasti dan berfikir secara rasional disebut dengan kemampuan berfikir kritis dengan berfikir kritis siswa dapat menyelesaikan permasalahan yang dihadapinya baik di dalam pembelajaran IPA maupun didalam lingkungan masyarakat dan mampu memecahkan permasalah tersebut dengan baik dan benar dan menemukan jawan yang paling tepat dari permasalahan yang dihadapinya tersebut (Sito'hang, 2010). Sejalan dengan pendapat yang sebelumnya Billy Tunas ( dalam sihotamg 2010) ia berpendapat bahwa kemampuan berfikir kritis sangat sejalan dengan kemaun diri sendiri dan merupan dasar dari disiplin diri, mamantau sendiri, dan memperbaiki pikiran sendiri untuk dapat memecahkan permasalahan sendiri dan mampu berkomunikasi lebih efektif. Begitupun dengan pendapat Aryana (dalam Dukalang, 2012) memodifikasi indikatorindikator kemampuan berpikir kritis Ernis menjadi enam kreteria dalam menilai kemampuan berpikir kritis meliputi merumuskan masalah, memberikan 
argumen, melakukan deduksi, melakukan induksi, melakukan evaluasi, dan mengambil keputusan dan tindakan. Kemampuan berfikir kritis siswa sangat rendah dalam pembelajaran ipa karena minat baca siswa yang sangat kurang dalam pembelajaran ipa sehingga diperlukan pembaharuan didalam pembelajaran yang menjadikan siswa memiliki minat untuk membaca dan meningkatkan berfikir kritis siswa dari materi atau pembelajarn ipa yang telah mereka baca tersebut. Pemilihan alternatif pembaharuan kegiatan pembelajaran yang berpotensi mampu mengatasi setiap permasalahan di kelas merupakan salah satu tindakan yang seharusnya dilakukan oleh guru sebagai garda terdepan dalam pendidikan. Pembaharuan dapat dilakukan melalui strategi pembelajaran ataupun dengan penggunaan produk di dalam pembelajaran yang menarik minat siswa untuk belajar, membaca dan otomatis akan membantu siswa untuk lebih mampu berpikir kritis (Maliki, 20ll:9). Salah satu produk dalam pembelajaran yaitu dengan menggunakana buku saku berbasis literasi yang menjadikan lebih menarik dan dapat memfasilitasi siswa menjadi pemikir yang aktif dan kritis Jadi semua siswa yang ada di sekolah terbantu dengan menggunakan buku saku berbasis literasi meningkatkan berfikir kritis pada siswa dengan meningkatnya minat baca siswa dengan menggunkan media pembelajaran yang menarik seperti ini.

Dengan adanya pengembangan buku saku berbasis literasi ini tentunya diharapkan agar dapat untuk meningkatkan berfikir kritis siswa dalam pembelajaran ipa sekolah dasar ini sangat penting disampaikan oleh pendidik. Melalui buku saku berbasis literasi diharapkan bisa mewujudkan peningkatan terhadapap kemampuan berfikir kritis siswa dalam pembelajaran ipa menjadi meningkat.

\section{Kajian Literatur}

Ilmu Pengetahuan Alam. Ipa merupakan ilmu yang berisi tentang cara mencari tahu tentang keadaan alam semesta secara sistematis, oleh sebabab itu pembelajaran ipa bukan hanya bukan hanya ilmu yang menguasi penguasaan konsep, fakta-fakta, ataupun ilmu-ilmu yang hanya memuat atau hanya mengkaji tentang prinsip- prinsi saja tetapi juga merupakan suatu proses penurunans. Pembelajaran IPA menjadi salah satu pembelajaran starategis agar menjadikan siswanya agar mampu menyiapkan sumber daya manusia yang nantinya akan siap menghadapi persaingan dimasa yang akan datang (Depdiknas 2006). Suastra (2006). Oleh sebab itu terwujudnya potensi ini apabila dalam pembelajaran IPA berhasil atau elah berhasil menjadikan siswa-siwa yang menguasai sains dan berhasil menumbuh kembangkan kemampuan berfikir kritis, berfikir logis, berfikir kreatif, adaptif dan berinisiatif terhadap perubahan pembaharuan pembangunan. Dengan demikian sangat diperlukan tranformasi pendidikan IPA yang proses pembelajaran semula hanya menghafal berubah menjadi proses pembelajaran yang lebih berfikir, dari semula belajara hanya secara dangkar berubah menjadi belajar jauh lebih dalam lagi atau kompleks dan dari orientasi pada transfer pengetahuan ke pengembangan kompetensi. Namun banyak ditemui dilapangan pada kenyataannya kebanyakan dalam pembelajaran IPA kemampuan berfikir kritis siswa masih sangat rendah hal ini mengakibatkan nilai pada pembelajaran ipa sangat rendah dan tujuan pembelajaranpun tidak tercapai dari permasalahan tersebut tentulah sangat penting adanya perbaikan pada proses pembelajaran ipa untuk meningkatkan kemampuan berfikir kritis pada siswa.

Pentingnya Buku Saku Berbasis literasi sains dalam meningkatkan kemampuan berfikir kritis pada sisw a Literasi sains diartikan sebagai kemampuan seseorang dimana dia mampu menguasai huruf dan pengetahuan atau disebut juga dengan seseorang yang tidak buta huruf. Kemampuan seseorang dalam menggunakan pengetahuan sains serta mampu mengidentifikasi pertanyaan dan menjadikan atau menemukan kesimpulan dari hal tersebut sesuai dengan buktibukti berkenaan dengan alam (OECD, 2003). Literasi sains menurut PISA diartikan sebagai " the capacity to use scientific knowledge , to identify questions and to draw evidence-based conclusions in order to understand and help make decisions about the natural world and the changes made to it through human activity". dari pendapat diatas literasi sains diartikan sebagai kemampuan siswa dimana dia mampu menggunakan pengetahuan sains,mengidentifikasi pertanyaan, dan mampu menarik kesimpulan berdasarkan bukti-bukti yang didapat serta mampu menghasilkan atau menarik kesimpulan berkenaan dengan perubahan yang terjadi dimana perubahan tersebut dilakukan melauli aktivitas manuusia yang berhubungan dengan alam.. Unsur pokok yang terdapat pada literasi sain s menurut Harlen (2004: 64) diantara nya adalah : I. concepts or ideas, whic to make sense of new experiences by linking them to what we already know; 2. processes, which are mental and physical skills used in obtaining, interpreting and using evidence about the world around to gain knowledge and build understanding; 3. attitudes or dispositions, which indicate willingness and confidence to engage in enquiry, debate and further learning. 4. understanding the nature (and limitations) of scientific knowledge. 
Dari pemaparan diatas dapat disimpulkan bahwa yang menjadi hal mendasar atau hal pokok yaitu pemahaman peserta didik tersebut terhadap sains sehingga siswa bukan hanya sekedar tahu tentang konsep sain tetapi siswa lebih memahaminya secara mendalam dimana konsep sains tersebut dinataranya terdiri dari pengetahuan tentang sains, proses sains,pengembangan sikap ilmiah, dan pemhaman siswa terhadap sains Berdasarkan penjelasan di atas dapat dijelaskan bahwa hal yang paling pokok dalam pengembangan literasi sains siswa meliputi pengetahuan tentang sains, proses sains, pengembangan sikap ilmiah, dengan demikian siswa kedepannya mampu memecahkan dan menghadapi permesalahan baik didalam pembelajaran maupun didalam kehidupan sehari-hari didalam lingkungan sekitarnya. Seseorang yang memiliki kemampuan literasi sains dan teknologi ditandai dengan kemampuan seseorang tersebut untuk berfikir secara kritis dalam menyelesaikan oermasalahan yang dihadapinya dalam kehidupan sehari-hari yaitu dengan menggunakan konsep-konsep sains dalam pendidikan sesuai dengan jenjang pedidikan seseorang tersebut serta mampu mengenal dan mengaplikasikan produk teknologi yang ditemuinya dan memeliharanya sehingga menghasilkan produk teknologi yang lebih kreatif hal ini akan menjadikan peserta didik untuk mampu mengambil keputusan dan kesimpulan dalam kehidupan berbudaya dan bermasyarakat nantinya (Peodjadin, et.al 20II:2) Jadi Buku Saku Berbasis literasi sains merupakan buku saku yang dirancang demi meningkatakn kemampuan berfikir kritis siswa buku saku berbasis literasi sains disini yaitu membuat buku yang berisi sains dengan kemampuan seseorang agar dapat menggunakan pengetahuan sains, mengidentifikasasi pertanyaan, serta mampu menghasilkan kesimpulan yang sesuai berdasarkan dengan bukti-bukti, sehingga siswa mampu mehami dan dari pehamman tersebut menghasilkan keputusan yang sesuai dengan keadaan alam melalui aktivitas manusia itu sendiri, jadi Jadi Buku Saku Berbasis literasi sains diharapkan dapat meningkatkan minat baca siswa pada pembelajaran ipa sehingga siswa dapat meningkatkan kemampuan berfikir kritis dari apa yang telah dibaca dan di pelajari dalam pembelajaran ipa.

Desain Pembuatan Buku Saku berbasis literasi Sains Dalam membuat rancangan Produk buku saku berbasis literasi sains, seorang peneliti harus memahami desain instruksional sehingga dapat menghasilkan produk yang efektif dan efisien. Desain instruksional merupakan suatu proses berurutan, logik dan rasional yang bertujuan untuk menyelesaikan masalah/program (Akhiar \& Shamsina, 2010)..Desain instruksional dapat dilihat sebagai sistem atau sebagai satu proses. Sebagai disiplin, desain pengajaran merupakan satu cabang pengetahuan berkait dengan kajian dan teori strategi pengajaran dalam hal ini ialah dalam pebuatan buku saku berbasis literasi sains. Dalam penelitian, peneliti mengembangkan produk berupa buku saku berbasis literasi sains. Rancangan dasar dan tahapan pengembangan pembelajaran mengacu pada desain instruksional model ADDIE (Analyze Design Develop Implement Evaluate)(Gagne et al. 2005). Model ADDIE dipilih karena berasaskan sistem yang melibatkan pembinaan bahan pengajaran untuk sesuatu kursus atau satu kurikulum. Model ini lazimnya digunakan oleh satu penelitian dalam menghasilkan produk. Jadi, salah satu fungsi ADDIE yaitu menjadi pedoman dalam membangun perangkat dan infrastruktur program pelatihan yang efektif, dinamis dan mendukung kinerja pelatihan itu sendiri. Model ADDIE ini menggunakan 5 tahap pengembangan yakni: (I) Analysis (analisis), (2) Design (disain/perancangan) (3) Development (pengembangan), (4) Implementation (implementasi/ pelaksanaan), (5) Evaluation (penilaian/evaluasi/umpan balik

\section{Objek Kajian}

Objek kajian ini yaitu untuk mengenal bagaimana merancang buku saku berbasis literasi sains agar dapat meningkatkan kemampuan berfikir kritis siswa dalam pembelajaran ipa di madrasah

\section{Metodologi Penelitian}

Desain dan Prosedur Penelitian yang akan dilaksanakan Pada penelitian buku saku berbasis literasi sains ini menggunakan metode penelitia RESEACRH and DEVELOPMENT atau disebut juga dengan penelitian pengembangan. Dimana pada desain penelitian ini dengan cara membuat buku saku berbasis literasi sains agar dapat mampu meningkatkan kemampuan berfikir kritis siswa pada pembelajaran IPA di tingkat madrasah dimana buku saku berbasis literasi ini bisa digunakan oleh siswa ataupun dibimbing oleh guru. Sementara pendekatan penelitian buku saku berbasis literasi sains ini menggunakan pendekatan penelitian (MIX METHOD) (kualitatif dan kuantitatif) yang nantinya akan menghasilkan buku saku berbasis literasi sain kemudian tahapan dalam penelitia pengembangan menggunaka ADDIE (Aderson\&Krathwohl, 200I: Dick and Carey, 2005; Gagne, et,al 2005). Pembuatan buku saku berbasis literasi.

2. Instrumen dan Teknik Pengambilan Data Instrument yang dipakai atau digunakan dalam penelitian pengembangan buku saku berbasis literasi sains ini adalah sebagai berukut yaitu tahap analisis, 
dimana hal ini dilakukan untuk menjawab tujuan dari penelitian dilakukan dengan metode MIX METOD, data diambil dengan teknik pengambilan data berupa subjek evaluasi terdiri atas uji ahli materi, uji ahli desain, uji kelompok kecil dan uji efektifitas. Uji ahli materi dilakukan oleh ahli bidang isi materi untuk mengevaluasi isi materi pembelajaran pada buku saku berbasis literasi sains, dan uji ahli dilakukan oleh ahli desain untuk mengevaluasi desain buku saku berbasis literasi sains. Uji kelompok kecil dilakukan pada 10 orang siswa untuk mengetahui peningkatan kemampuan berfikir kritis pada siswa. Pada hasil analisi akan dijadikan acuan untuk penilaian produk yang jemudian dijadikan sebagai dasar dalam proses pembuatan buku saku berbasis literasi sains. Hal yang dilakukan dalam proses ini yitu menentukan materi mana saja yang akan dimuat dalam pembuatan dan pengembangan buku saku berbasis literasi sains tersebut.

\section{Rujukan}

Arikunto, S. 2012. Prosedur Penelitian (Suatu Pendekatan Praktis). Jakarta: PT. Rineka Cipta.

Bigge, M.L. (1982). Learning Theories for Teachers. Fourth Edition. Cambridge: Harper \& Row.

Desmita. (2005). Psikologi Perkembangan. Bandung: PT Remaja Rosdakarya.

Kurniawati, I. D., Wartono., \& Diantoro, M. (20I4). Pengaruh Pembelajaran Inkuiri Terbimbing Integrasi Peer Instruction terhadap Penguasaan Konsep dan Kemampuan Berpikir Kritis Siswa. Jurnal Pendidikan Fisika Indonesia. I0(I) 3646. DOI: 10.15294/jpfi.v10il.3049.

Lalang, A. C., Ibnu, S., \& Sutrisno. (2017). Kemampuan Berpikir Kritis dan Pemahaman Konseptual Siswa dengan Inkuiri Terbimbing dipadu Pelatihan Metakognisi pada Materi Kelarutan dan KSP. Jurnal Pendidikan: Teori, Penelitian, dan Pengembangan, 2(I), I2-2I. Retrieved from http://journal.um.ac.id/index.php/jptpp/article/vi ew/8372/40I6.

Merta, I Wayan. 20II. Efektivitas Model-Model Pembelajaran Inovatif Terhadap Konsep Diri dan Keterampilan Berpikir Kritis Siswa Dalam Pembelajaran Sains. Jurnal Ikatan Keluarga Alumni (IKA). Volume 09, No.2 September 20I I. Singaraja: Undiksha.

Muspawi, Muhamad. 2014. Kreatifitas Guru Dalam Menggunakan Media Pembelajaran. Jurnal Penelitian Universitas Jambi Seri Humaniora Vol 15.

Pangestu, Abdurrahman, Sesunan. 2013. Pengembangan Buku Saku Ipa Terpadu Sebagai
Media Pembelajaran Berbasis Literasi Sains Siswa SMP. Jurnal Pendidikan Fisika FKIP Unila.

Sugiyono. 2010. Metode Penelitian Pendidikan (Pendekatan Kuantitatif, Kualitatif dan R\&D), Bandung: Alfabeta.

Susilo, A. B., Wiyanto., \& Supartono. (20I2). Model Pembelajaran IPA berbasis Masalah untuk Meningkatkan Motivasi Belajar dan Berpikir Kritis. Unnes Science Education Journal, I(I), |4-20. doi.org/l0.15294/usej.vlil.849.

Wells, B. (1987) Apprenticeship in Literacy. Dalam Interchange 18,1/2:109-123. 